\title{
The difference of the salivary volume before and after drinking the rosella tea (Hibiscus sabdariffa)
}

\author{
Mutiara Indah Permata Sari Islami*, Edeh Roletta Haroen*, Sri \\ Tjahajawati* \\ *Department of Oral Biology Faculty of Dentistry Universitas Padjadjaran
}

\begin{abstract}
Introduction: Roselle plants (Hibiscus sabdariffa) is one of the herbs that began to be used by the community. Benefits of this plant is quite a lot for health. The portion taken for consumption is the red flower petals. oselle tea is one of the sour beverages which can affect the salivary gland secretion. The purpose of this study is to analyzed the difference of salivary volume before and after drinking roselle tea. Methods: This study has been conducted to 40 students of Faculty of Dentistry, Padjadjaran University, ranging from 18-23 years of age with good general condition. This study is quasi-experimental in vitro study using the paired test analysis with $a=0,05$ of the data collected from salivary volume. Results: The result of study indicates that the average of salivary volume before drinking roselle tea is 1,90 milliliter. After drinking roselle tea, the average of salivary volume is 4,54 milliliter. The result of paired test analysis shows that $\mathrm{t}$-test is 16,172 and $\mathrm{t}$-table is 2,022 . The value of $\mathrm{t}$-test $>\mathrm{t}$-table. Result of statistic shown there is significant difference of salivary volume before and after drinking roselle tea. Conclusion: There is a difference of salivary volume before and after drinking roselle tea.
\end{abstract}

Keywords: Salivary volume, Roselle tea (Hibiscus sabdariffa).

\section{INTRODUCTION}

The use of herbal plants as traditional medicine has long been known by people around the world. In Indonesia, the tradition of traditional medicine with herbs has been passed down from generation to generation. ${ }^{1}$ Herbal medicine treatment is increasingly used by the community because its natural content is believed to be safer than chemical treatment. In addition, economic factors also play a role in the selection of natural treatment. ${ }^{2}$

Roselle plants (Hibiscus sabdariffa) is one of the herbs that began to be used by the community. Benefits of this plant is quite a lot for health.
The portion taken for consumption is the red flower petals. The use of unlimited rosella flower petals is consumed freshly, but also processed into a brewed drink known as rosella tea. ${ }^{3}$ The content of roselle petals is quite complete, consisting of vitamins A, B1, B2, C, D, flavonoids, gossypetine, hibiscetine, sabdaretine, calcium, magnesium, beta-carotene, phosphorus, iron, organic acids, polysaccharides, omega-3, a mixture of citric acid and malic acid, and essential amino acids. The highest content is a mixture of citric acid and malic acid. The results showed that the content of vitamin $C$ in rosella flower petals 3 times more than black grapes, 9 times from 
oranges, 10 times from starfruit, and 2.5 times from guava. Citric acid, malic acid, and vitamin C cause roselle to be acid. ${ }^{3,4}$ Sour taste is one of the chemical stimuli that can stimulate salivary gland secretion and cause increased salivary volume in the mouth. ${ }^{5}$ In the world of dentistry, the role of saliva is very important to maintain oral health. In addition to help the digestive process of food, saliva also plays a role in the process of lubrication, tasting, cleansing, maintaining body fluid balance, and inhibit the growth of bacteria in the mouth. ${ }^{6}$

If salivary gland secretion is reduced, there is a decrease in salivary volume in the mouth. Reduced salivary volume, resulting in various complaints, such as dry mouth, decreased taste, difficulty chewing and swallowing, pain of the tongue and mucosa, and inflammation of the mouth. One stimulus that can increase salivary gland secretion is chemical stimuli. Chemical stimuli consist of acidic, sweet, salty, and bitter stimuli. ${ }^{5}$

Rosella tea is a type of beverage that can stimulate salivary gland secretion due to its high acid content. Increased secretion of salivary glands causes increased salivary volume in the mouth. Therefore, the authors are interested to conduct research on the difference in salivary volume before after drinking rosella tea. The aim of this study was to analyzed differences salivary volume before taking after drinking rosella tea and to obtain data of salivary volume difference before after drinking rosella tea.

\section{METHODS}

The type of research used is pseudo-experimental, ie research by controlling other factors that can influence the results of research outside factors to be studied. ${ }^{7}$ The study was conducted by measuring salivary volume before after drinking rosella tea. The study population is preclinical student of Faculty of Dentistry, Padjadjaran University. Sample in this research is saliva taken from 30 student, selected by purposive sampling technique, that is taking subject based on certain purpose and fulfill some criterion. ${ }^{8,9}$ Samples to be taken meet the population criteria of men and women, have good general health, good dental and oral health, do not use orthodontic appliances or prostheses, are not taking any medications that may affect salivary gland secretion, not smoking, and are willing to participate as sample in research by signing informed consent.

\section{RESULTS}

The research was conducted on 40 students of Preclinic Faculty of Dentistry Padjadjaran University. Each sample is asked to spit saliva that has been collected with the position of the head down and accommodated with a measuring cup. From the research that has been done, obtained saliva volume data before by after drinking rosella tea drink on 40 sample as contained in the appendix section of this thesis. The saliva volume in the 40th after the drinking of rosella tea was higher than before taking rosella tea. At the time before drinking rosella tea, this saliva volume has the lowest value of 1 milliliter and the highest value of 3.5 milliliters, while at the time after drinking rosella tea, saliva volume has the lowest value of 2.5 milliliters and the highest value of 7 milliliter.

Differences in saliva volume in 40 sample before after drinking rosella tea is very varied. The salivary volume difference ranges from 0.5 milliliters to 4.5 milliliters. Furthermore, to see the general difference in salivary volume before taking after drinking rosella tea, calculated the mean salivary volume value before after taking the rosella tea drink. Here the researcher depicts a bar graph showing the average saliva volume before taking after drinking rosella tea.

Based on Graph 1, it was found that the average value of salivary volume before drinking rosella tea was 1.9 milliliters. However, after drinking rosella tea, the average salivary volume increased to 4.5 milliliters. So it can be seen an increase in the average salivary volume before the after drinking rosella tea drink of 2.6 milliliters.

This means an increase in salivary volume after drinking rosella tea is more than twice that of drinking before taking rosella tea. However, to determine whether the difference in salivary volume before and after taking rosella tea drink is significant or not, the researcher performs t-test statistic for paired data. To test the difference of salivary volume before and after drinking rosella tea, it is necessary to test the hypothesis proposed as follows: HO, BO: Nosignificant differencebetween thevolume 
Graphic 1. Comparison of average number of thevolume of saliva before and after drinking rinse of Roselle Tea

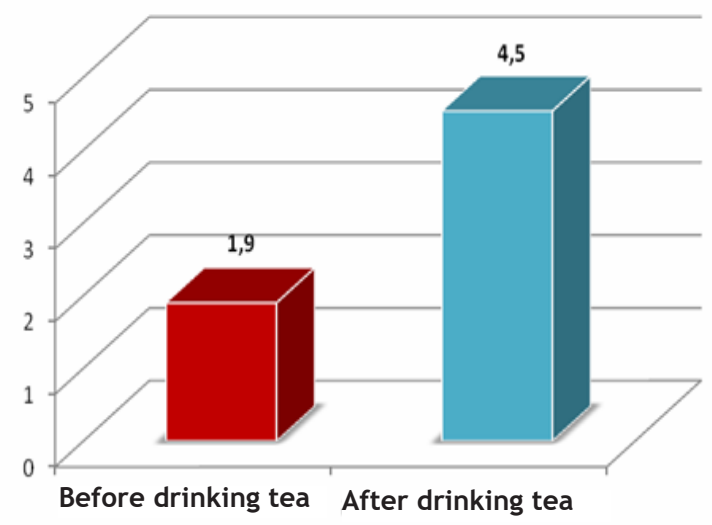

Table 1. Saliva Salivary Difference Test Result Before After Drinking Rinse of Rosella Tea

\begin{tabular}{|c|c|c|c|c|}
\hline $\begin{array}{c}\text { Paired Sample } \\
\text { Test }\end{array}$ & $\mathrm{t}$-count & $\mathrm{t}$-table & Sig. & $\begin{array}{c}\text { Test } \\
\text { Result }\end{array}$ \\
\hline $\begin{array}{c}\text { The volume of } \\
\text { saliva before and } \\
\text { after drinking } \\
\text { rinse of Rosella } \\
\text { Tea }\end{array}$ & 16,172 & 2,022 & 0,000 & $\begin{array}{c}\text { H0 reject- } \\
\text { ed }\end{array}$ \\
\hline
\end{tabular}

of saliva beforeand after drinking rinse of RoselleTea $\mathrm{H} 1$ B0: There is significant difference between the volume of saliva before and after drinking rinse of Roselle Tea Coefficient correlation (a) used in this research is $5 \%$. Based on the tests performed using SPSS 15.0 for Windows software, the following statistical test results " $t$ " in pairs as shown in the following table: Table 1 shows the $\mathrm{t}$-count of 16.172 and the $\mathrm{t}$-table value of 2.022 . Since the $\mathrm{t}$-count is greater than the $\mathrm{t}$-table at $\alpha=0.05$, the test decision is to reject $\mathrm{HO}$. This means that there is a difference between salivary volume before and after taking rosella tea drink. Thus it can be said that rosella tea is a health drink that can increase the volume of saliva for people who consume it.

\section{DISCUSSION}

Acidity is a chemical stimulus that can increase salivary volume. ${ }^{5}$. Drinking rosary acid tea is acidic, including chemical stimulants that can increase salivary volume. By drinking rosella tea drink can maintain healthy teeth and mouth, because if the salivary volume increases then the saliva function in the oral cavity, especially the function of saliva in self-cleansing will run better. ${ }^{10,11}$
The method used in saliva collection is the spitting method or the method of spinning. ${ }^{12}$ The highest salivary flow rate occurs during the day, so daytime becomes the standard time for salivary flow measurements. Body position may affect salivary gland secretion. In standing position, salivary gland secretion can reach $100 \%{ }^{13}$ Saliva volume before drinking rosella tea tea is 1.9 milliliters and after drinking rosella tea drink rises up to 4.5 milliliters. The data showed that the average saliva volume before drinking rosella tea was smaller than the average salivary volume after drinking rosella tea. After statistical tests with $a=0.05$ obtained $t$-count (16.172) is greater than t-table (2.022), then the test decision is to reject $\mathrm{H} 0$. Based on the discussions that have been described, it can be concluded that there is a significant difference of salivary volume before after drinking rosella tea.

\section{CONCLUSION}

There is a difference in salivary volume before after drinking rosella tea drink.

\section{REFERENCES}

1. Pattiasina S. Tanaman obat Indonesia. $1^{\text {st }}$ Ed. 2009. $116 \mathrm{pp}$

2. Tobing P. Hidup sehat dengan herbal. 2009. $537 \mathrm{pp}$.

3. Widyanto PS, Nelistya A. Rosella : Aneka Olahan, Khasiat, \& Ramuan. Jakarta : Penebar Swadaya. 2008. 2-12 pp.

4. Maryani H. Kristiana L. Khasiat \& Manfaat Rosela : Revisi. Jakarta Selatan : PT. Agromedia Pustaka. 2008. 1-9, 25-26 pp.

5. Amerongen VN. Ludah dan Kelenjar Ludah : Arti bagi Kesehatan Gigi. Terj. R. Abyono dan S. Suryo. Yogyakarta : Gadjah Mada University Press. 1991. 1-41, 179, 194, 202-205 pp.

6. Rensburg BGJV. Oral Biology. Chicago : Quintensence Publishing Co. Inc. 1995. 459, 462, 464-466, 470, 474-477 pp.

7. Notoatmodjo S. Metodologi Penelitian Kesehatan. Jakarta : PT Rineka Cipta. 2002. 158-159 pp.

8. Sudjana. Metode Statistika. Edisi ke-6. Bandung : Penerbit Tarsito. 2005. 183, 242 pp.

9. Arikunto S. Prosedur Penelitian Pendekatan 
Suatu Praktik. Edisi Revisi IV. Jakarta : Rineka Cipta. 2006. 139-140 pp.

10. Guyton AC, Hall JE. Buku Ajar Fisiologi Kedokteran. 9th Ed. Terj.I. Setiawan, Ken A. T. dan A. Santoso. Jakarta : Buku Kedokteran EGC. 2006. 1016-1018 pp.

11. Mozartha, 2008. Saliva atau air liur. [online]. Available at : www.klikdokter.com (diakses
November 2008).

12. Navazesh, M. and C. M. Christensen. 1982. A comparison of whole mouth resting and stimulated salivary measurement procedures. J. Dent. Rest 61:1158-1162.

13. Roth, G. I. and R. Calmes. 1981. Oral Biology. St. Louis: The C.V. Mosby Co. Pp. 196, 204205, 210-211, 214. 